\title{
Prospek Konseling Komunitas bagi Individu Eks-Pecandu Narkoba (Studi Pada Lembaga Pasca-Rehabilitasi Narkoba Di Kota Semarang)
}

\author{
Rudi Haryadi \\ Program Studi Bimbingan dan Konseling, Fakultas Keguruan dan Ilmu Pendidikan, Universitas Islam \\ Kalimantan MAB Banjarmasin ${ }^{1}$ \\ Banjarmasin; haryadi413@gmail.com
}

Submitted: 30-05-2018, Revised: 10-06-2018, Accepted: 20-06-2018

\begin{abstract}
Despite being free from addiction, ex-drug addict clients are by no means free from problems at all. The potential for recurrence is still a scourge to watch out for. In this case the counselor faces new challenges to be able to provide services to this population. While post-rehabilitation institutions have been popping up in big cities, one of them is Semarang. This study aims to analyze the implementation of services in post-rehabilitation institutions in the city of Semarang, and assess how the prospects of community counseling if implemented in this institution. The case study was conducted at two post-rehabilitation institutions in Semarang City. Data collection techniques used by researchers are observation, interview, documentation study, and spreading of SOAR based questionnaire. The results found that there are similarities in the implementation of post-rehabilitation programs with a comprehensive counseling framework, but they have some drawbacks due to the lack of professional qualifications and empirical theoretical studies in them. The researcher then recommends the counselor to carry out appropriate standards-based community counseling on clients of drug addicts by taking into account all the resources, aspirations, opportunities, and expected performance.
\end{abstract}

Keywords: Ex-Drug Addict; Community Counseling; Counselor Addiction; After-Care Agency

\begin{abstract}
Abstrak: Meskipun telah terbebas dari adiksi, klien eks-pecandu narkoba bukan berarti telah bebas dari masalah sama sekali. Potensi untuk kambuh kembali masih menjadi momok yang perlu diwaspadai. Dalam hal ini konselor mengadapi tantangan baru untuk mampu memberikan pelayanan pada populasi ini. Sementara lembaga pascarehabilitasi telah banyak bermunculan di kota-kota besar, salah satunya adalah Semarang. Penelitian ini bertujuan untuk menganalisis pelaksanaan pelayanan dalam lembaga pasca-rehabilitasi di kota Semarang, dan menilai tentang bagaimana prospek konseling komunitas jika diterapkan dalam lembaga ini. Studi kasus dilakukan pada dua lembaga pasca-rehabilitasi di Kota Semarang. Teknik pengumpulan data yang digunakan peneliti adalah pengamatan, wawancara, studi dokumentasi, dan penyebaran kuesioner berbasis SOAR. Hasilnya menemukan bahwa terdapat kemiripan pelaksanaan program perbantuan pada lembaga pasca-rehabilitasi dengan kerangka kerja konseling komprehensif, hanya saja memiliki beberapa kekurangan akibat minimnya kualifikasi profesional dan kajian teoretis-empiris di dalamnya. Peneliti kemudian merekomendasikan konselor untuk melaksanakan konseling komunitas yang sesuai standar pada klien eks-pecandu narkoba dengan mempertimbangkan segenap sumber daya, aspirasi, kesempatan, dan capaian yang diharapkan.
\end{abstract}

Kata Kunci: Eks-Pecandu Narkoba; Konseling Komunitas; Konselor Adiksi; Lembaga Pasca-Rehabilitasi

\section{Pendahuluan}

Salah satu hal yang sejak dulu menjadi permasalahan dalam masyarakat dan membutuhkan perhatian khusus adalah penyalahgunaan obat-obatan. Maraknya peredaran dan penyalahgunaan NAPZA dan obat-obatan terlarang diakui banyak kalangan menjadi ancaman yang berbahaya. Survei nasional penyalahgunaan narkoba yang dilaksanakan oleh Badan Narkotika Nasional (BNN) terhadap 13.710 responden yang terdiri dari pelajar SLTP, SLTA dan mahasiswa pada tahun 2013 menyebutkan data bahwa dalam setahun terakhir terdapat $3,9 \%$ responden yang menyalahgunakan narkoba (BNN, 2015). Ini menunjukkan bahwa 
permasalahan tentang kecanduan ini tidak bisa diremehkan dan membutuhkan partisipasi semua kalangan serta profesi dalam upaya pencegahan maupun penanganan.

Terdapat tiga tahapan penanganan pada klien pecandu narkoba, yaitu detoksifikasi, rehabilitasi, dan pasca-rehabilitasi (BNN, 2015). Bagi klien yang ingin berhenti dari kecanduannya harus menjalani proses detoksifikasi untuk membersihkan fisik dari zat-zat adiktif dalam tubuhnya melalui pendekatan medis. Setelah bersih klien kemudian harus menjalani proses rehabilitasi untuk melatih perubahan gaya hidup bebas narkoba. Pada tahap ini klien harus menjalani sejumlah terapi psikologis untuk merekonstruksi fungsi kognitif dan melepaskan diri dari jeratan adiksi yang dialaminya (UNODC, 2016). Klien akan dinyatakan boleh kembali ke masyarakat apabila telah menjalani proses ini.

Meskipun dapat dikatakan telah bebas dari adiksi setelah menjalani proses detoksifikasi dan rehabilitasi, bantuan pada klien eks-pecandu narkoba tidak serta merta berhenti begitu saja. Data dari Badan Nasional Narkotika (BNN), Rumah Sakit Ketergantungan Obat (RSKO), dan Kepolisian Republik Indonesia (POLRI) menunjukkan bahwa sekitar 65,17\% penyalahguna narkoba yang mengikuti program rawat inap dan rawat jalan adalah para pengguna lama yang mengalami relapse (Astuti \& Ismandari, 2014). Artinya potensi untuk kambuh kembali menggunakan narkoba (relapse) masih sangat besar.

Fakta empiris menunjukkan bahwa kebanyakan dari klien eks-pecandu narkoba memang masih terbayangi rasa takut akan kambuh (relapse) jika kembali pada lingkungan mereka yang lama. Rasa takut ini cukup beralasan, sebab telah ditemukan bahwa faktor interpersonal menunjukkan hubungan kuat dengan kekambuhan. Jika individu berada di lingkungan sosial yang negatif di mana mereka berada dalam kontak dengan orang yang menggunakan narkoba, mereka sekitar dua setengah kali lebih mungkin untuk kambuh menggunakan alkohol atau narkoba (Chong \& Lopez, 2008). Kembali pada lingkungan yang lama mungkin terjadi karena mereka tidak memiliki efikasi diri yang kuat untuk menghadapi masyarakat. Kurangnya efikasi diri pada klien eks-pecandu narkoba justru juga menjadi salah satu faktor penyebab kekambuhan Hal ini membuat mereka menjadi pribadi yang sangat sensitif, mudah emosional dan mudah stres oleh tekanan sosial dari lingkungan. (Ibrahim \& Kumar, 2009).

Kejadian yang penuh stres terkait dengan simtom yang dieksternalisasi, seperti agresi dapat mengarahkan pada alienasi sebaya atau penerimaan secara sosial dari teman sebaya yang kemudian akan mengarah pada peningkatan penggunaan narkoba (King \& Chassin, 2008). Belum lagi mengenai faktor tekanan dan hubungan keluarga yang kurang baik juga dapat menjadi penyebab kambuh menggunakan narkoba (Bhandari, Dahal, \& Neupane, 2015). Ini merupakan permasalahan stigma negatif yang mereka hadapi. Stigma ini terus terjadi karena sudah menjadi persepsi umum masyarakat bahwa individu eks-pecandu narkoba dianggap sebagai kriminal, sampah masyarakat, atau orang yang menyeramkan (Brooks \& McHenry, 2015). Tumbuhnya persepsi negatif di lingkungan akan semakin menurunkan efikasi diri subyek eks-pecandu sehingga menghambat proses re-integrasinya dengan lingkungan baru (Ibrahim \& Kumar, 2009).

Padahal jika seseorang terlibat dalam beberapa jenis pekerjaan atau sibuk dalam beberapa kegiatan lain di masyarakat, maka ada kemungkinan kurang terlibat dalam penyalahgunaan narkoba dan meningkatkan kemungkinan untuk lebih menghindari kekambuhan penggunaan obat (Bhandari, Dahal, \& Neupane, 2015). Dengan kata lain memberikan tujuan tertentu dalam kehidupan eks-pecandu narkoba seperti pekerjaan dan kegiatan dapat menekan kecenderungan relapse. Memiliki tujuan yang lebih besar dalam hidup dapat memberikan motivasi untuk secara konstruktif belajar dari pengalaman, menaksir peristiwa negatif secara adaptif, dan menghindari kecenderungan melamun yang negatif. Sebab komponen tujuan hidup adalah salah satu aspek yang berkontribusi tinggi pada komitmen berkarir (Strauser, Lustig, \& Çıftçı, 2008). 
Dengan memiliki tujuan dalam hidup, individu eks-pecandu narkoba akan mendapatkan kekayaan sumber daya yang bisa digunakan untuk mengatasi situasi, memotivasi secara adaptif dan proaktif dalam penanganan situasi, menyangga efek samping pengalaman, dan dengan demikian memfasilitasi serta mendorong pembelajaran dan pengembangan keterampilan regulasi emosi yang lebih besar seiring waktu (Schaefer, et al., 2013). Sebaliknya, rendahnya tujuan hidup juga memprediksi kekambuhan pada klien eks-pecandu narkoba (Martin, MacKinnon, Johnson, \& Rohsenow, 2011).

Sejalan dengan studi lain, harapan akan masa depan yang diperoleh dari pelajaran hidup dan keinginan untuk melakukan perubahan yang terdapat dalam diri pecandu juga berperan dalam proses penyembuhan kecanduan narkoba. Adanya harapan akan masa depan dalam diri eks-pecandu narkoba dapat menjadi motivasi bagi mereka untuk memperbaiki kualitas hidup dan terbebas dari narkoba (Aztri \& Milla, 2013). Harapan ini perlu dikelola dan direalisasikan dalam upaya untuk membantu klien eks-pecandu narkoba bertahan dalam kondisi abstinen.

Salah satu harapan subyek eks-pecandu narkoba adalah kembalinya kondisi yang mereka miliki sebelum menggunakan zat adiktif (NIDA, 2012). Proses pemulihan klien ekspecandu narkoba hakikatnya tidak hanya sampai pada keputusan berhentinya seseorang dari kecanduan, melainkan terus berlangsung seumur hidup. Kontinuitas pemulihan perlu dipertahankan oleh seorang eks-pecandu narkoba agar tidak kembali pada kondisi teradiksi.

Di sinilah profesi bimbingan dan konseling mendapatkan tantangan. Konselor harus mampu bekerja di berbagai macam setting untuk meningkatkan kepercayaan dalam lingkup masyarakat yang lebih luas. Ini akan mewujudkan legitimasi bahwa konselor diperlukan dimana saja (Gladding, 2012). Dalam populasi ini, peran konselor sebagai profesional diperlukan sebagai psikoedukator dalam membantu klien eks-pecandu narkoba sehingga mereka dapat mempertahankan kondisi abstinen mereka serta kembali menjadi pribadi yang berfungsi penuh dalam kehidupan bermasyarakat.

Karena perilaku manusia sangat terkait dengan konteks dimana individu tersebut berada, maka untuk memberi bantuan pada orang-orang yang berada dalam populasi ini, konselor perlu bekerja dalam lingkup yang lebih luas. Tidak hanya bekerja dalam lingkup individual, namun juga konselor perlu bekerja dalam lingkup masyarakat. Konseling komunitas dapat dimaknai sebagai sebuah kerangka bantuan komprehensif yang didasarkan pada kompetensi multikultural dan berorientasi pada keadilan sosial (Lewis, Lewis, Daniels, \& D'Andrea, 2011). Konselor pada lingkup komunitas menggunakan strategi yang memfasilitasi pengembangan kesehatan mental baik klien secara individu pembelaan pada komunitas yang melingkupinya. Dengan kata lain, idealnya pemberian bantuan pada klien ekspecandu narkoba tidak hanya terbatas dalam tataran individual yang sempit, melainkan perubahan lingkungan yang lebih kondusif bagi mereka juga perlu diusahakan oleh konselor.

Terkait pemberian bantuan pada klien eks-pecandu narkoba, Kota Semarang telah memiliki lembaga pasca-rehabilitasi yang berfokus pada pencegahan relapse dan pengembangan diri klien. Hanya saja tidak lebih dari $10 \%$ tenaga perbantuan yang memberikan pelayanan di dalamnya telah memiliki kualifikasi sebagai profesional. Ini merupakan sebuah prospek besar bagi profesi konselor dalam melebarkan tataran pelayanannya. Sebagaimana dikemukakan oleh Prayitno, Wibowo, Marjohan, Mugiarso, \& Ifdil (2015) kini profesi bimbingan dan konseling di Indonesia tidak lagi dibatasi hanya di sekolah, melainkan juga menjangkau bidang-bidang di luar sekolah yang memberikan nuansa dan corak edukatif nonformal, pengembangan sumber daya manusia serta warga masyarakat.

Berdasarkan rasional tersebut, maka penelitian ini bertujuan untuk: (1) mengungkap isi dan pelaksanaan program pelayanan pada klien eks-pecandu narkoba yang telah terlaksana di Kota Semarang; dan (2) menganalisis bagaimana prospek pelaksanaan konseling komunitas yang komprehensif dalam rangka menyediakan perbantuan ideal bagi klien eks-pecandu narkoba di Kota Semarang. Hasil penelitian ini akan memberikan pandangan mengenai 
prospek pelayanan bimbingan dan konseling bagi klien eks-pecandu narkoba di Kota Semarang, maupun secara umum.

\section{Metode Penelitian}

Penelitian ini menggunakan desain studi kasus. Pengamatan, wawancara, dan studi dokumentasi dilaksanakan pada lembaga-lembaga pasca-rehabilitasi narkoba di Kota Semarang. Dalam hal ini peneliti melaksanakan studi di dua lembaga, yaitu Rumah Damping ASTAMA dan Rumah Damai. Hal ini bertujuan untuk menemukan pemahaman dasar mengenai bagaimana pelaksanaan program pasca-rehabilitasi yang telah berjalan selama ini. Peneliti menggunakan metode pengamatan sebagai partisipan untuk melihat secara langsung bagaimana proses pemberian layanan, treatment, dan kegiatan yang dilaksanakan dalam kedua lembaga tersebut. Peneliti kemudian melakukan wawancara terhadap 2 orang pengurus pada masing-masing lembaga dan mengumpulkan dokumen-dokumen terkait pelaksanaan program. Analisis kualitatif dengan metode Miles, Huberman, \& Saldana (2014) kemudian dilakukan terhadap hasil dari ketiga teknik pengumpulan data yang didapat dari kedua sumber data tersebut. Dengan analisis ini, data melalui proses: (1) pengumpulan; (2) kondensasi; (3) penyajian; dan (4) interpretasi.

Selain itu peneliti juga menggunakan kuesioner dengan pendekatan SOAR (Strength, Opportunity, Aspiration, dan Result) untuk menemukan sejauh mana potensi untuk diterapkannya konseling komunitas yang komprehensif bagi klien eks-pecandu narkoba di Kota Semarang. Kuesioner ini disebarkan kepada seluruh klien eks-pecandu narkoba di Rumah Damping ASTAMA dan Rumah Damai. Tercatat sebanyak 40 responden telah mengisi kuesioner. Kebutuhan akan konseling komunitas kemudian diinterpretasikan berdasarkan penjabaran mengenai keempat aspek tersebut.

\section{Hasil dan Pembahasan}

Dari analisis data yang dilakukan oleh peneliti, ditemukan beberapa hasil yang dapat dijabarkan menjadi sebagai berikut:

\section{Pelaksanaan Program Pelayanan di Lembaga Pasca-Rehabilitasi di Kota Semarang}

Berdasarkan data yang didapat dari Rumah Damping ASTAMA dan Rumah Damai, kondensasi data dilakukan dengan melakukan koding terhadap setiap data hasil pengamatan, wawancara, dan studi dokumentasi pada setiap sumber data. Hasil kondensasi data selanjutnya menyajikan data mengenai kondisi faktual pelaksanaan konseling komunitas klien eks-pecandu narkoba di Kota Semarang secara umum. Berikut adalah temuan akhir yang didapatkan:

1. Lembaga pasca-rehabilitasi eks-pecandu narkoba di Kota Semarang telah memiliki program layanan yang dijalankan secara harian dan mingguan. Total waktu pelaksanaan program bervariasi dari 50 hari hingga 360 hari. Klien wajib mengikuti program selama waktu yang telah diprogramkan oleh lembaga.

2. Pelayanan dalam lembaga pasca-rehabilitasi eks-pecandu narkoba di Kota Semarang dilaksanakan dan dikelola oleh pihak pendamping yang memiliki latar belakang pendidikan berbeda-beda, 90\% di antaranya bukan berasal dari bidang profesional kesehatan, psikologi, konseling atau pekerja sosial. Mayoritas pendamping teridentifikasi sebagai ekspecandu narkoba juga. Upaya profesionalisasi dilakukan melalui pelatihan kompetensi pendamping yang dilaksanakan oleh lembaga yang bekerjasama dengan komunitas.

3. Pendamping dalam lembaga pasca-rehabilitasi eks-pecandu narkoba di Kota Semarang berperan untuk menjalankan seluruh program yang disusun, melakukan pendampingan pada klien, dan memfasilitasi seluruh kebutuhan klien selama menjalani program.

4. Klien yang tergabung dalam lembaga pasca-rehabilitasi eks-pecandu narkoba di Kota Semarang umumnya terbagi atas mereka yang bergabung secara sukarela, dan mereka yang mendapat rujukan dari keluarga, atau lembaga lain. 
5. Pelayanan dalam lembaga pasca-rehabilitasi narkoba di Kota Semarang dikemas dalam sistem asrama. Sebagian lembaga memiliki aturan yang ketat terkait dengan penggunaan alat komunikasi dan interaksi dengan masyarakat di luar asrama. Sebagian lagi lebih longgar dalam aturan ini.

6. Lembaga pasca-rehabilitasi narkoba di Kota Semarang telah memiliki program-program pelayanan yang wajib untuk diikuti oleh seluruh klien eks-pecandu narkoba yang terdaftar di dalamnya. Program-program tersebut dijabarkan pada tabel 1.

7. Selain program wajib yang telah terencana, lembaga pasca-rehabilitasi narkoba di Kota Semarang juga terbuka pada program atau pelaksanaan layanan yang bersifat insidental. Biasanya program insidental dilaksanakan oleh pihak-pihak lain.

Tabel 1. Daftar Program Pelayanan pada Lembaga Pasca-Rehabilitasi di Kota Semarang

\begin{tabular}{|c|c|c|}
\hline Program & Tujuan & Porsi \\
\hline Asesmen urin (tes) & $\begin{array}{l}\text { Mengetahui kondisi penggunaan NAPZA pada } \\
\text { klien eks-pecandu narkoba untuk menilai } \\
\text { seberapa jauh tingkat abstinensi klien. }\end{array}$ & $5 \%$ \\
\hline Asesmen tes kesehatan mental & $\begin{array}{l}\text { Mengetahui tingkat kesehatan mental, } \\
\text { kemampuan kognisi, dan kepribadian klien. }\end{array}$ & $5 \%$ \\
\hline Asesmen non tes (wawancara) & $\begin{array}{l}\text { Menilai permasalahan yang dialami oleh masing- } \\
\text { masing klien dalam sebelum dan selama } \\
\text { menjalani masa program. }\end{array}$ & $6 \%$ \\
\hline $\begin{array}{l}\text { Support Group (Morning \& } \\
\text { Evening Meeting) }\end{array}$ & $\begin{array}{l}\text { Memfasilitasi dukungan moril antar sesama klien } \\
\text { eks-pecandu narkoba yang berkeinginan untuk } \\
\text { mempertahankan masa abstinen dan memulai } \\
\text { hidup sehat. }\end{array}$ & $40 \%$ \\
\hline Relapse Prevention & $\begin{array}{l}\text { Membekali klien dengan pengetahuan dan } \\
\text { keterampilan yang dapat digunakan untuk } \\
\text { menolak pengaruh-pengaruh negatif dari dalam } \\
\text { diri dan lingkungan yang dapat memicu } \\
\text { kekambuhan penggunaan narkoba. }\end{array}$ & $2 \%$ \\
\hline $\begin{array}{l}\text { Pelatihan keterampilan vokasi } \\
\text { (budidaya jamur, membuat batik, } \\
\text { membuat kerajinan tangan, } \\
\text { memasak, pelatihan cukur } \\
\text { rambut) }\end{array}$ & $\begin{array}{l}\text { Membekali klien dengan keterampilan yang } \\
\text { bermanfaat agar mampu berwirausaha dan } \\
\text { mandiri dalam bekerja sebagai bagian dari proses } \\
\text { re-integrasi dengan masyarakat. }\end{array}$ & $24 \%$ \\
\hline Intervensi berbasis spiritual & $\begin{array}{l}\text { Memperkuat nilai-nilai religius yang ada dalam } \\
\text { diri klien dan mengembangkannya untuk } \\
\text { mencegah kemungkinan terjadi relapse di masa } \\
\text { depan. }\end{array}$ & $10 \%$ \\
\hline Konseling perorangan & $\begin{array}{l}\text { Mengentaskan masalah yang dialami oleh klien } \\
\text { terkait dengan kehidupan secara pribadi baik } \\
\text { sebelum dan selama menjalani masa program. }\end{array}$ & $3 \%$ \\
\hline Rekreasi dan hiburan & $\begin{array}{l}\text { Menjaga stabilitas mental klien selama menjalani } \\
\text { masa program agar tidak mengalami kejenuhan } \\
\text { dan stres. }\end{array}$ & $5 \%$ \\
\hline Home visit & $\begin{array}{l}\text { Membangun komunikasi dengan pihak keluarga } \\
\text { klien untuk memantau perkembangan klien } \\
\text { setelah menjalani program pasca-rehabilitasi. }\end{array}$ & $7 \%$ \\
\hline
\end{tabular}

Melihat hasil temuan studi, lembaga pasca-rehabilitasi eks-pecandu narkoba di Kota Semarang memang telah melaksanakan berbagai program. Walau begitu, varian intervensi yang diberikan masih sangat minim. Padahal pemberian bantuan pada klien eks-pecandu 
narkoba dapat mencakup pada area yang lebih luas dibandingkan hanya berfokus pada pengembangan klien saja. Idealnya fokus utama sebuah komunitas adalah menyediakan lingkungan yang kondusif dan memfasilitasi keadilan sosial bagi klien yang tergabung di dalamnya (Lee, 2007). Sebab perkembangan sebuah komunitas bergantung pada perkembangan klien atau anggota yang terlibat di dalamnya. Begitupun sebaliknya, perkembangan klien sangat bergantung pada perkembangan komunitas itu sendiri (Lewis, Lewis, Daniels, \& D'Andrea, 2011).

Tabel 1 menunjukkan bahwa belum ada upaya terprogram dari lembaga yang ditujukan untuk memfasilitasi perubahan masyarakat guna mengurangi stigma dan diskriminasi pada individu eks-pecandu narkoba. Hal ini sangat disayangkan mengingat bahwa konseling dalam lingkup komunitas memiliki potensi fleksibilitas yang tinggi dalam hal pemberian intervensi (Lewis, Toporek, \& Ratts, 2010), termasuk di antaranya adalah dengan memfasilitasi pelaksanaan advokasi dan perubahan sosial tingkat makro.

Pengaruh lingkungan eksternal adalah faktor penting yang menyebabkan penyalahgunaan narkoba (Abdu-Raheem, 2013). Bukti ini menunjukkan bahwa lingkungan tempat dimana individu berada memberikan pengaruh pada individu tersebut. Dalam dunia adiksi terutama, jika klien berada di lingkungan sosial yang negatif di mana mereka berada dalam kontak dengan orang yang menggunakan narkoba, mereka sekitar dua setengah kali lebih mungkin untuk kambuh menggunakan narkoba dalam 6 atau 12 bulan (Chong \& Lopez, 2008). Maka sangat penting untuk menciptakan kondisi lingkungan yang kondusif dalam tingkat sosial-masyarakat untuk memberikan dukungan pada klien eks-pecandu narkoba dalam proses pengembangan diri mereka.

Di banyak tempat, bentuk konseling pada individu eks-pecandu narkoba yang tersedia sering tidak efektif, tidak didukung oleh bukti ilmiah, dan kadang-kadang tidak sejalan dengan prinsip-prinsip hak asasi manusia dan tidak sukarela. Hal ini juga berlaku di negara-negara yang sangat maju di mana ketersediaan program intervensi sering tidak memiliki bukti atau data yang cukup dapat dipertanggungjawabkan secara empirik (UNODC, 2016). Kondisi faktual yang ditemukan peneliti menunjukkan adanya kekurangan ini dalam pelayanan di lembaga pasca-rehabilitasi di Kota Semarang. Porsi pelaksanaan layanan yang diberikan tidak seimbang. Beberapa pelayanan yang sangat penting justru tidak diberikan porsi yang lebih banyak dibanding dengan pelayanan yang lain, misalnya seperti konseling perorangan dan program relapse prevention. Padahal potensi relapse pada subyek eks-pecandu narkoba masih sangat besar (Astuti \& Ismandari, 2014). Idealnya kedua layanan ini diperlukan sebagai fokus yang harus mendapatkan porsi lebih banyak.

Hal lain yang sangat disayangkan adalah tidak adanya standarisasi waktu dalam pemberian intervensi. Terlihat dari jauhnya perbedaan masa program antara kedua komunitas yang diteliti menandakan bahwa ukuran baku untuk masalah lama program belum ada. Disebutkan dalam suatu penelitian bahwa pelaksanaan terapi berbasis komunitas ditemukan seringkali tidak efektif karena faktor internal seperti non-standarisasi waktu pelaksanaan intervensi (Ginting, Priyanti, Hilderia, \& Andriansyah, 2014). Dengan kata lain, pelakasanaan layanan perbantuan yang dilaksanakan di Kota Semarang mungkin saja belum bisa dikatakan sebagai best-practice karena masalah waktu yang tidak terstandar ini.

\section{Prospek Konseling Komunitas bagi Klien Eks-Pecandu Narkoba di Kota Semarang}

Temuan studi yang telah dipaparkan sebelumnya telah memberikan pemahaman mengenai pelaksanaan pelayanan perbantuan pada lembaga pasca-rehabilitasi eks-pecandu narkoba di Kota Semarang. Melihat program yang dilaksanakan, ini bisa menjadi sebuah masukan dan potensi tersendiri bagi profesi bimbingan dan konseling untuk mengembangkannya menjadi program konseling komunitas yang lebih komprehensif. Guna memenuhi prospek tersebut, maka hasil analisis kuesioner dengan pendekatan SOAR berikut 
akan memberikan masukan pada potensi apa yang dapat dikembangkan lebih lanjut dari program pelayanan yang telah terlaksana. Analisis SOAR dibagi menjadi 4 bagian, yang menganalisa potensi kekuatan, kesempatan, aspirasi, dan hasil yang diharapkan dari program pelayanan lembaga pasca-rehabilitasi eks-pecandu narkoba di Kota Semarang. Hasil analisis SOAR dipaparkan pada tabel 2 berikut.

Tabel 2. Hasil Analisis SOAR

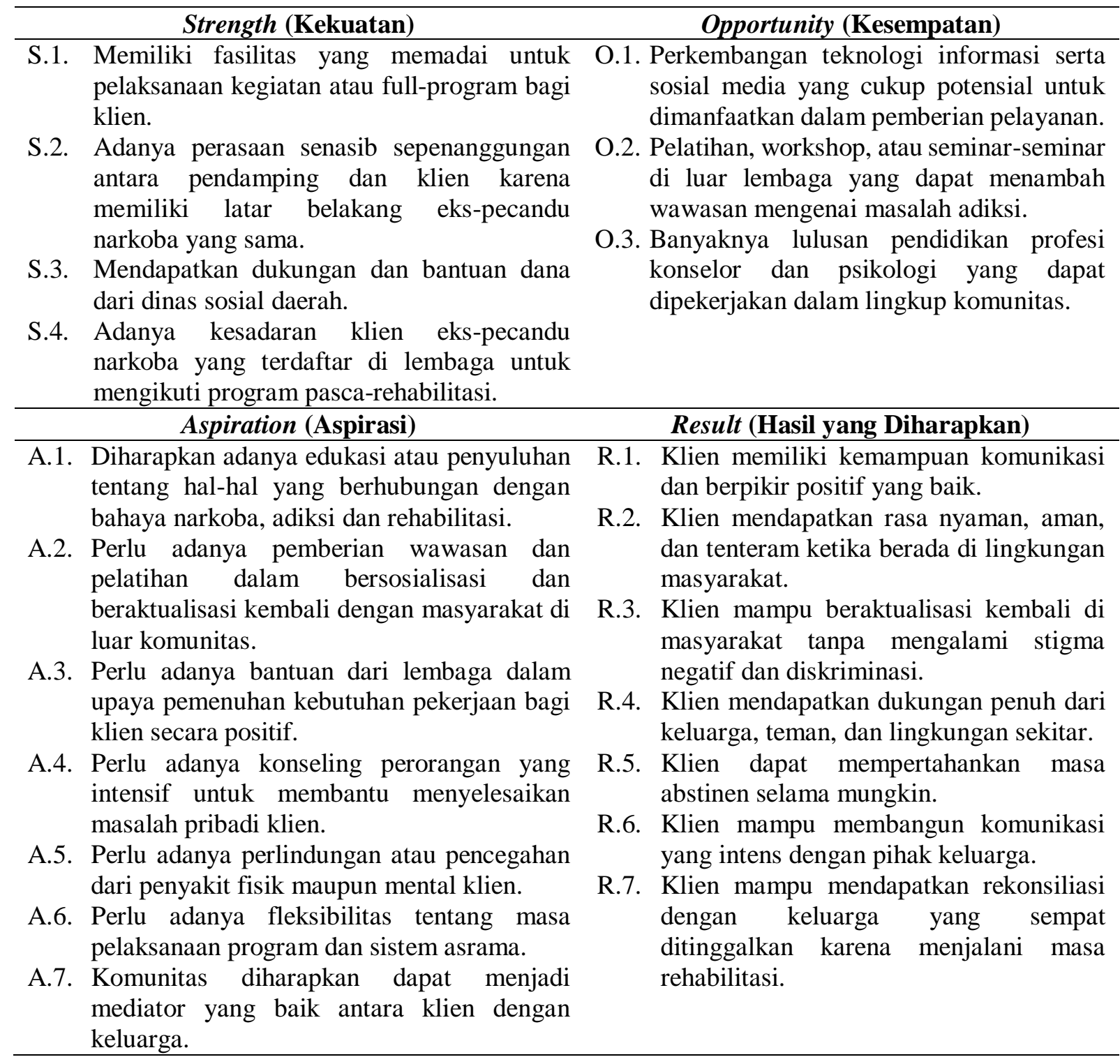

Analisis SOAR telah menemukan kebutuhan-kebutuhan baik bagi komunitas maupun klien eks-pecandu narkoba yang tergabung di dalamnya. Kebutuhan-kebutuhan tersebut dicitrakan oleh aspek kekuatan komunitas, kesempatan yang dapat dimanfaatkan, aspirasi klien, dan hasil yang diinginkan oleh segenap personel komunitas. Kelemahan tidak dilihat dalam analisis ini karena dengan berfokus pada kekuatan, komunitas dapat mengetahui hal-hal apa yang peerlu dipertahankan dan diperkuat sehingga kelemahan yang dimiliki akan teratasi dengan sendirinya (Stavros \& Cole, 2013). Kebutuhan untuk memanfaatkan potensi positif dari komunitas ini diperkuat dengan kesempatan yang ada di lingkungan untuk membuat komunitas berkembang. 
Pendekatan yang memperhatikan aspek kekuatan dan kesempatan ini dapat memfasilitasi pengembangan konseling komunitas secara komprehensif. Pengembangan komunitas dilakukan dengan melakukan kolaborasi sistemik antar setiap komponen pendukung yang ada dalam komunitas (Lewis, Lewis, Daniels, \& D'Andrea, 2011). Hasil analisis kekuatan dan kesempatan komunitas pada penelitian ini mengidentifikasi pentingnya pemanfaatan teknologi dan kerjasama antar lembaga dalam upaya pemulihan klien eks-pecandu narkoba. Pemanfaatan kesempatan-kesempatan ini tentu memperkuat kekuatan yang sudah dimiliki sebelumnya, seperti adanya kekompakan dan kekeluargaan dalam komunitas, multikulturalisme yang mewarnai komunitas, dan intervensi-intervensi kesehatan mental yang sudah ada. Selain itu tersedianya fasilitas dan biaya dapat menjadi potensi kekuatan yang perlu dioptimalkan oleh konselor untuk mengelola konseling komunitas yang komprehensif.

Sedikit berbeda dengan pengembangan komunitas, pengembangan klien secara terfokus dapat diidentifikasi kebutuhannya melalui aspek aspirasi dan hasil yang diinginkan dalam analisis SOAR. Analisis menunjukkan adanya salah satu kebutuhan akan pelayanan yang inovatif dan efisien. Sebagaimana diketahui, pelayanan yang efektif dan efisien dapat diperoleh melalui evidence-based practice (Konstam, Cook, Tomek, Mahdavi, Gracia, \& Bayne, 2015). Evidence-based practice (EBP) dapat menyediakan sebuah intervensi dengan dukungan empiris yang memadai terkait dengan subyek yang dituju (Melnyk, FineoutOverholt, Stillwell, \& Williamson, 2010). Kesesuaian dengan kebutuhan ini tentu semakin menimbulkan optimisme terhadap penggunaan EBP dalam program yang dikembangkan.

Kebutuhan berikutnya adalah dukungan dan hubungan yang kondusif. Munculnya kebutuhan ini dalam analisis SOAR dapat dikatakan wajar karena hal ini adalah kebutuhan umum pada subyek yang terlibat masalah adiksi. Sudah menjadi hal yang umum bahwa persepsi masyarakat tentang eks-pecandu narkoba adalah kriminal, sampah masyarakat, atau orang yang menyeramkan (Brooks \& McHenry, 2015). Terutama media-media biasanya menyoroti pecandu narkoba sebagai mereka yang tertangkap oleh penegak hukum dan menjadi narapidana karena telah mengkonsumsi zat adiktif yang ilegal. Hal ini tentu mempengaruhi persepsi lingkungan tentang klien eks-pecandu narkoba.

Tumbuhnya persepsi negatif di lingkungan mampu menurunkan efikasi diri subyek ekspecandu sehingga menghambat proses re-integrasinya dengan lingkungan baru (Ibrahim \& Kumar, 2009). Hal ini karena mereka terus ditandai sebagai individu yang 'tidak baik' atau 'sampah masyarakat' bahkan setelah mereka dibebaskan dari pusat rehabilitasi, sehingga menyebabkan mereka merasa tidak nyaman untuk berbaur dengan masyarakat, merasa lebih dikucilkan, harga diri rendah, dan merasa ditinggalkan. Jangankan di masyarakat, stigma ini bahkan juga terjadi dalam lingkungan keluarga klien eks-pecandu narkoba. Hal ini pada akhirnya menjadi faktor yang mendorong mereka kembali pada kebiasaan lama.

Tertolaknya klien eks-pecandu narkoba dari masyarakat dapat menyebabkan mereka kembali pada lingkungan yang lama. Hasil penelitian menunjukkan bahwa faktor interpersonal antar sesama pecandu menunjukkan hubungan kuat dengan kekambuhan. Jika klien berada di lingkungan sosial yang negatif di mana mereka berada dalam kontak dengan orang yang menggunakan alkohol atau obat-obatan lain, mereka sekitar dua setengah kali lebih mungkin untuk kambuh menggunakan alkohol atau narkoba dalam 6 atau 12 bulan, dengan pengguna narkoba berisiko lebih besar (Chong \& Lopez, 2008). Tanpa dukungan yang tepat, klien ekspecandu narkoba dapat terjerumus kembali pada potensi relapse.

Diketahui bahwa hubungan kekeluargaan menjadi faktor pelindung bagi individu ekspecandu narkoba yang dapat mengurangi kemungkinan relapse (Giordano, Clarke, \& Furter, 2014). Dengan demikian dengan memberikan dukungan dan membina hubungan yang kondusif dalam model yang dikembangkan, maka dapat mengurangi potensi relapse dan membantu klien eks-pecandu narkoba untuk tetap bertahan pada masa abstinen. 
Tema kebutuhan yang ketiga adalah perlunya edukasi dan pelatihan keterampilan pada klien eks-pecandu narkoba. Salah satu harapan klien eks-pecandu narkoba adalah kembalinya kondisi yang mereka miliki sebelum menggunakan zat adiktif (NIDA, 2012). Proses pemulihan klien eks-pecandu narkoba hakikatnya tidak hanya sampai pada keputusan berhentinya seseorang dari kecanduan, melainkan terus berlangsung seumur hidup. Kontinuitas pemulihan perlu dipertahankan oleh seorang eks-pecandu narkoba agar tidak kembali pada kondisi teradiksi. Kondisi pulih dan bersih dari kecanduan bagi subyek eks-pecandu NAPZA ini disebut sebagai masa abstinen (BNN, 2015).

Dengan karakteristik sebagai individu eks-pecandu narkoba yang telah mengalami hambatan dalam proses koginitf kompleksnya (Smith, 2015), orang-orang pada populasi ini sangat rentan dengan tekanan, kecemasan, atau depresi. Mereka sangat sensitif, mudah emosional dan mudah stres oleh tekanan sosial dari lingkungan (Ibrahim \& Kumar, 2009). Untuk itu klien eks-pecandu narkoba memerlukan arahan dan edukasi tentang berbagai hal yang terkait dengan dunia adiksi. Keterampilan-keterampilan koping atau relapse prevention juga perlu dilatihkan lebih intens pada klien eks-pecandu narkoba untuk membantu mereka menolak pikiran negatif, kecenderungan-kecenderungan yang mengarah pada kekambuhan.

\section{Simpulan dan Saran}

Secara garis besar, pelaksanaan program pelayanan perbantuan di lembaga pascarehabilitasi eks-pecandu narkoba di Kota Semarang memilki banyak kemiripan dengan program konseling komprehensif yang telah diketahui bersama. Meskipun memiliki beberapa kekurangan karena faktor profesionalisme dan kurangnya kajian teoretis serta bukti empiris, hal ini justru menjadi sebuah kesempatan yang besar untuk penerapan konseling komunitas yang komprehensif oleh konselor profesional. Dengan kesadaran, pengetahuan yang luas, dan keterampilan yang memadai, konselor dapat memfasilitasi pengembangan diri klien sekaligus pengembangan komunitas melalui perubahan-perubahan sosial untuk menciptakan lingkungan yang kondusif bagi klien eks-pecandu narkoba, sehingga dapat terwujud keadilan sosial bagi klien pada populasi ini.

Melalui hasil penelitian ini, peneliti kemudian merekomendasikan kepada konselor profesional untuk mempertimbangkan individu eks-pecandu narkoba sebagai prospek yang potensial dalam pengembangan setting pelayanan bimbingan dan konseling. Selain itu, dalam memberikan pelayanan terhadap populasi ini, konselor perlu menggunakan kerangka kerja konseling komunitas yang komprehensif guna mengoptimalkan sumber daya yang tersedia, melalui pertimbangan akan aspirasi serta kesempatan yang ada.

\section{Daftar Pustaka}

Abdu-Raheem, B. O. (2013). Sociological Factors To Drug Abuse And The Effects On Secondary School Students' Academic Performance In Ekiti And Ondo States, Nigeria. Contemporary Issues in Education Research , 6 (2), 233-240.

Astuti, R., \& Ismandari, F. (2014). Gambaran Umum Penyalahgunaan Narkoba di Indonesia. Buletin Jendela Data dan Informasi Kesehatan. I, pp. 1-52. Jakarta: Kementrian Kesehatan RI.

Aztri, S., \& Milla, M. N. (2013). Rasa Berharga Dan Pelajaran Hidup Mencegah Kekambuhan Kembali Pada Pecandu Narkoba Studi Kualitatif Fenomenologis. Jurnal Psikologi , 9 (1), 48-63.

Bhandari, S., Dahal, M., \& Neupane, G. (2015). Factors Associated With Drug Abuse Relapse: A Study On The Clients Of Rehabilitation Centers. Al-Ameen Journal of Medicine and Science, 8 (4), 293-298.

BNN. (2015). Laporan Akhir Survei Nasional Perkembangan Penyalahgunaan Narkoba Tahun Anggaran 2014. Jakarta: Badan Narkotika Nasional Indonesia. 
Brooks, F., \& McHenry, B. (2015). A Contemporary Approach to Substance Use Disorders and Addiction Counseling. Alexandria, VA: American Counseling Association.

Chong, J., \& Lopez, D. (2008). Predictors of Relapse for American Indian Women After Substance Abuse Treatment. Journal of The National Center , 14 (3), 24-47.

Gani, S. (2013). Therapeutic Community (TC) pada Residen Penyalah Guna Narkoba di Panti Social Marsudiputra Dharmapala Inderalaya Sumatera Selatan. Jurnal Konseling dan Pendidikan, 1 (1), 54-57.

Ginting, E. Y., Priyanti, E., Hilderia, D., \& Andriansyah, D. (2014). Pengaruh Pelaksanaan Metode Therapeutic Community Terhadap Kesembuhan Pecandu Narkoba di Sibolangit Center. Jurnal Pendidikan Antropologi , 1-12.

Giordano, A. L., Clarke, P. B., \& Furter, R. T. (2014). Predicting Substance Abuse Relapse: The Role of Social Interest and Social Bonding. Journal of Addiction and Counseling , 35, 114-127.

Gladding, S.T. (2012). Konseling: Profesi yang Menyeluruh (Terjemahan). Jakarta: Indeks.

Ibrahim, F., \& Kumar, N. (2009). Factors Effecting Drug Relapse in Malaysia: An Empirical Evidence. Asian Social Science, 5 (12), 37-44.

Konstam, V., Cook, A., Tomek, S., Mahdavi, E., Gracia, R., \& Bayne, A. H. (2015). EvidenceBased Practice, Work Engagement and Professional Expertise of Counselors. The Professional Counselor , 5 (1), 67-80.

Lee, C. C. (2007). Social Justice: A Moral Imperative for Counselors. Alexandria, VA: American Counseling Association.

Lewis, J. A., Lewis, M. D., Daniels, J. A., \& D'Andrea, M. J. (2011). Community Counseling: A Multicultural-Social Justice Perspective (4th ed.). Belmont, CA: Brooks/Cole, Cengage Learning.

Lewis, J. A., Toporek, R. L., \& Ratts, M. (2010). Advocacy and Social Justice: Entering the Mainstream of the Counseling Profession. In M. Ratts, R. L. Toporek, \& J. A. Lewis, ACA Advocacy Competencies: A Social Justice Framework for Counselors (pp. 239244). Alexandria, VA: American Counseling Association.

Martin, R. A., MacKinnon, S., Johnson, J., \& Rohsenow, D. J. (2011). Purpose in life predicts treatment outcome among adult cocaine abusers in treatment. Journal of Substance Abuse Treatment , 40, 183-188.

Melnyk, B. M., Fineout-Overholt, E., Stillwell, S. B., \& Williamson, K. M. (2010). The Seven Steps of Evidence-Based Practice. American Journal of Nursery, 110 (1), 51-53.

NIDA. (2012). Addiction Science: From Molecules to Managed Care (2nd ed.). Bethesda, MD: National Institute on Drug Abuse.

Prayitno, Wibowo, M. E., Marjohan, Mugiarso, H., \& Ifdil. (2015). Pembelajaran Melalui Pelayanan BK di Satuan Pendidikan: Pengembangan Manusia Seutuhnya. Yogyakarta: Paramitra Publishing.

Schaefer, S. M., Boylan, J. M., Reekum, C. M., Lapate, R. C., Norris, C. J., Ryff, C. D., et al. (2013). Purpose in Life Predicts Better Emotional Recovery for Negative Stimuli. Plos ONE , $8(11), 1-9$.

Smith, R. L. (2015). Treatment Strategies for Substance and Process Addiction. USA: American Counseling Association.

Stavros, J. M., \& Cole, M. L. (2013). SOARing towards positive transformation and change. The ABAC ODI Visions.Action.Outcome. , 1 (1), 10-34.

Strauser, D., Lustig, D., \& Çıftçı, A. (2008). Psychological well-being: its relation to work personality, vocational identity, and career thoughts. Journal of Psychology, 142, 2135. 
UNODC. (2016). International Standards for The Treatment of Drug Use Disorders. Vienna, Italy: Commission on Narcotic Drugs, WHO. 
